\title{
Adoption of agricultural technology and its influence on productivity and competitiveness of maize in the central-eastern region of the state of Puebla, Mexico
}

\author{
Juan Velázquez López ${ }^{1}$ \\ José Pedro Juárez Sánchez ${ }^{2 *}$ \\ Benito Ramírez-Valverde ${ }^{2}$ \\ Juan Jiménez Morales ${ }^{2}$ \\ Oswaldo Rey Taboada Gaytán² \\ Manuel del Valle Sánchez ${ }^{3}$
}

\begin{abstract}
The objective of this study was to determine the competitiveness and level of technology adoption by maize producers in two municipalities in the central-eastern state of Puebla, Mexico. A survey was applied to a sample of 95 producers considering socio-demographic, economic and agronomic variables. Data was obtained from production units located in the 5 agrosystems classified in the study area. Competitiveness and level of technology adoption were determined by the Formal Tech Adoption Index (FTAI), which for the region studied was medium; the Tlachichuca agrosystem had the highest value with 53.66. In the Degree of Employment of Peasant Technologies (DEPT), the Sierra agrosystem was highest (66.66); the Tlachichuca and Sierra agrosystems had the two highest average grain yield with 3.54 and 3.73 t.ha ${ }^{-1}$, respectively. It was concluded that the adoption of technology is a factor that determines the productivity and competitiveness of maize production in the study area. Another important variable in competitiveness was price.
\end{abstract}

Keywords: Agrosystem, peasant production system, smallholdings, rainfed agriculture.

\section{Adopción de tecnología agrícola y su influencia en la productividad y competitividad del maíz en el centro-oriente del estado de Puebla, México}

\section{Resumen}

El objetivo de este estudio fue determinar la competitividad y el grado de adopción de tecnología por los productores de maíz en dos municipios del centro-oriente del estado de Puebla, México. Se aplicó un cuestionario a una muestra de 95 productores considerando variables sociodemográficas, económicas y agronómicas. La información se obtuvo de unidades de producción ubicadas en los cinco agrosistemas en que se ha clasificado la zona de estudio. Se determinó la competitividad y el nivel de adopción de tecnologías a través del Índice de Apropiación de Tecnologías Formales (IATF), el cual para la región estudiada fue medio; el agrosistema de Tlachichuca el más alto con 53.66. En el Grado de Empleo de Tecnologías Campesinas (GETC), el agrosistema de Sierra fue superior (66.66); en ambos agrosistemas tuvieron los rendimientos promedio más altos de 3.54 y $3.73 \mathrm{t} \cdot \mathrm{ha}^{-1}$, respectivamente. Se concluyó que la adopción de tecnología es un factor que determina la productividad y la competitividad de la producción de maíz en la zona de estudio. Otra variable importante en la competitividad fue el precio.

Palabras clave: Agrosistema, sistema de producción campesino, minifundio, agricultura de temporal.

'Colegio de Postgraduados Campus Puebla, Programa de Estrategias para el Desarrollo Agrícola Regional, km 125.5, Carretera Federal México-Puebla, C.P. 72760. ${ }^{2}$ Colegio de Postgraduados Campus Puebla, km 125.5, Carretera Federal México-Puebla, C.P.72760.

${ }^{3}$ Universidad Autónoma Chapingo, carretera México-Texcoco, km 38.5, C.P. 56230, Chapingo, Texcoco Edo. de México.

*Corresponding author: pjuarez@colpos.mx

Received: February 1, 2019.

Accepted: June 18, 2019. 


\section{Introduction}

In the last decades of the 20th century, the Mexican government changed its economic development model with the objective of strengthening its economic competitiveness; to achieve this, it followed a strategy that favors free trade and private investment. The market became the regulating organ of the economy, affecting diverse sectors, among them the agricultural sector.

When the North American Free Trade Agreement came into force in 1994, the agricultural sector was inserted into an unfavorable economic dynamic by eliminating trade barriers; three products were classified as "sensitive" (maize, beans and powdered milk). It was envisioned that in 15 years maize would be internationally competitive, and for this purpose, an agricultural policy was designed that would lower its costs and increase its production and productivity. For this, a tariff of $\$ 215.0$ per ton was determined as an import quota and would be progressively decreased (Centro de Estudios de las Finanzas Públicas-CEFP, 2007).

Since the economic depression of 2008, maize was the most difficult crop due to the disappearance of protectionist tariffs and quotas (GonzálezEstrada \& Alférez, 2010). This translated into lags in production and impacted the trade deficit; in 2012 there was a deficit in the state of Puebla of 797.8 t (García \& Ramírez, 2012), which represented $84.6 \%$ of production that year. The prediction made by public policy ideologues when considering that maize was cheaper to import than to produce it in the country was erroneous; this was not the case, so the implemented agricultural policy generated severe disadvantages for maize producers leading them to crisis.

Despite the situation in the agricultural sector, it is still important, not only in terms of food production, but also in terms of the number of people employed. The Instituto Nacional de Estadística y Geografía (INEGI, 2010c) reports that $22.2 \%$ of the country's Economically Active Population (EAP) works in the primary sector; and in the same year, it employed $22 \%$ of the EAP of the state of Puebla, representing a population of 1271562 people (Comisión Estatal del Componente de Desarrollo de Capacidades y Extensionismo Rural-CECODECER, 2013).

\section{Introducción}

En las últimas décadas del siglo $\mathrm{XX}$, el gobierno mexicano cambió su modelo de desarrolloeconómico con el objetivo de fortalecer su competitividad económica; para lograrlo, siguió una estrategia que favorece el libre comercio y la inversión privada. El mercado se constituyó en el órgano regulador de la economía afectando a diversos sectores, entre ellos el agropecuario.

Al entrar en vigor el Tratado de Libre Comercio de América del Norte -1994-, el sector agrícola fue insertado en una dinámica económica desfavorable al eliminar las barreras comerciales, tres productos -maíz, frijol y leche en polvo-fueron clasificados como "sensibles". Se vislumbraba que en 15 años el maíz sería competitivo internacionalmente y para ello, se diseñó una política agrícola que disminuiría sus costos y aumentaría su producción y productividad. Para ello, le fue determinado un arancel de \$215.0 por tonelada como cuota de importación e iría disminuyendo de manera progresiva (Centro de Estudios de las Finanzas Públicas-CEFP, 2007).

A partir de la depresión económica del 2008, el cultivo de maíz fue el que mostró mayores dificultades a causa de la desaparición de los aranceles y cuotas proteccionistas (González-Estrada \& Alférez, 2010). Ello se tradujo en rezagos en su producción e impactó en el déficit de la balanza comercial, en 2012 se registró un déficit en el estado de Puebla de 797.8 t (García \& Ramírez, 2012), que representó, el $84.6 \%$ de la producción de ese año. Resultó erróneo el pronóstico que realizaron los ideólogos de la política pública al considerar que el maíz era más económico importarlo que producirlo en el país, y no fue así, debido a que la política agrícola implementada generó severas desventajas para los productores de maíz llevándolos a la crisis.

A pesar de la situación por la que atraviesa el sector agrícola, sigue siendo importante, no solo por la producción de alimentos, sino también, por el número de personas que emplea. El Instituto Nacional de Estadística y Geografía (INEGI, 2010c), menciona que el $22.2 \%$ de la Población Económicamente Activa (PEA) del país, labora en el sector primario; y en el mismo año empleaba al $22 \%$ de la PEA del estado Puebla, representando una población de 1 271562 personas (Comisión Estatal del Componente 
On the other hand, in the agricultural sector of the United States most of the farms have between 61.1 and 178.5 hectares and use between 1 and $2 \%$ of the EAP. This indicates that with increased technology, U.S. farmers are employing less and less labor over a larger area and with high productivity (Economic Report of the President, 2006). Here, technology has replaced the use of labor (Hayami \& Rutan, 1973), especially those related to mechanical innovations that allow generally scarce work to be more productive. In 1940 an American farmer could feed 20 people and today he feeds 155 (Buffet, 2013), an increase of $800 \%$.

In Mexico, maize is the main crop in terms of cultivated area, 7.48 million hectares (SIAP, 2013), and per capita consumption, $74 \mathrm{~kg}$ per year (Del Valle \& Perales 2014), making it a vital product for food security. This gives importance in political, economic and cultural terms (Sweenely, Steigerwald, Davenport, \& Eakin, 2013), being instituted in a conjunctural axis for the development of hundreds of generations (Villa, Robles, Barrueta, \& Herrera, 2010). Currently, the PROAGRO program provides $\$ 860.0$ per hectare to producers who have more than 5 hectares registered and $\$ 1000.0$ to those who have less than 5 ha; however, the average production cost of a hectare of maize ranges between 6 and 7 thousand pesos. The objective of this research was to analyze whether the adoption of technology influenced the competitiveness of peasants of rainfed maize in the agrosystems of the municipalities of Tlachichuca and Chalchicomula de Sesma in the state of Puebla.

\section{Adoption of technology}

For decades, researchers such as Doss (2006) Feder, Just and Zilberman (1985), Feder and Umali (1993) and Lee (2005) argued that the adoption of agricultural technology is a fundamental aspect of increasing production and productivity of available resources; but it is also a vital instrument in profitability and competitiveness of the sector (Seixas \& Ardila, 2002), specifically for small producers who are immersed in an increasingly competitive market on a global scale, as well as between industries and countries (Williams, 2007). de Desarrollo de Capacidades y Extensionismo RuralCECODECER, 2013).

En cambio, en el sector agrícola de los Estados Unidos la mayor parte de las granjas tienen una extensión entre las 61.1 y las 178.5 hectáreas y ocupa entre el 1 y $2 \%$ de la PEA. Esto indica que con una mayor tecnología los granjeros estadounidenses emplean cada vez menos mano de obra en una mayor superficie y con una elevada productividad (Economic Report of the President, 2006). Aquí, la tecnología ha permitido sustituir el empleo de mano de obra (Hayami \& Rutan, 1973), especialmente, las que tienen que ver con las innovaciones mecánicas que permiten que el trabajo generalmente escaso pueda tener una mayor productividad. En 1940 un granjero estadounidense podía alimentar a 20 personas y hoy en día alimenta a 155 (Buffet, 2013), significó un incremento del $800 \%$.

En México, el maíz es el principal cultivo, tanto por su superficie sembrada -7.48 millones de hectáreas(SIAP, 2013) como por su consumo per cápita -74 kg anuales-(DelValle\&Perales 2014), constituyéndoseen un producto vital para la seguridad alimentaria. Esto le da relevancia en términos políticos, económicos y culturales (Sweenely, Steigerwald, Davenport, \& Eakin, 2013); instituyéndose en un eje coyuntural para el desarrollo de cientos de generaciones (Villa, Robles, Barrueta, \& Herrera, 2010). Actualmente el programa PROAGRO apoya con $\$ 860.0$ por hectárea a los productores que tienen más de 5 hectáreas registradas y $\$ 1000.0$ a los que tienen menos de 5 ha; sin embargo, el costo de producción promedio de una hectárea de maíz oscila entre los 6 y 7 mil pesos. El objetivo de la investigación fue analizar si la adopción de tecnología influyó en la competitividad de los agricultores de maíz de temporal en los agrosistemas de los municipios de Tlachichuca y Chalchicomula de Sesma en el estado de Puebla.

\section{La adopción de tecnología}

Durante décadas, investigadores como Doss (2006) Feder, Just y Zilberman (1985), Feder y Umali (1993) y Lee (2005) argumentaron que la adopción de tecnología agrícola es un aspecto fundamental para incrementar la producción y la productividad de los recursos disponibles; pero también es un instrumento 
Competitiveness research constitutes an extensive literature, consisting of both theoretical and empirical studies (Lambrecht, Vanlaue, Merckx, \& Maertens, 2014). In the latter, at the micro level, it has been demonstrated that agricultural intensification through the diffusion and adoption of better technology contributes to reducing poverty and food insecurity (Shiferaw, Kebede, \& You, 2008; Kijima, Otsuka, \& Sserukuuma, 2008). Most of these studies were conducted in developing countries focusing on the socioeconomic characteristics of the production unit, such as the availability of capital or credit constraints, among others (Zeller, Diagne, \& Mataya, 1998). Other studies have focused on a specific technology and on the sequence of steps that make up the adoption of the elements of a technological package (Aldana, Foltz, Barham, \& Useche, 2011; Byerlee \& de Polanco, 1986).

Ramírez (1999), when evaluating the technology for maize recommended by the "Plan Llanos de Serdán" in the eastern part of the state of Puebla, defined the adoption of technology as the appropriate use of new agricultural technologies to improve crop management and increase yields per hectare; it is also the way producers combine production factors in each of the agricultural practices and the productivity of the factors is expressed in yields per hectare (Damian-Huato, et al., 2009). Galindo (2004) establishes that the adoption of technology is a mental process, in which peasants, after having information for the first time about an innovation, make the decision to accept or reject it under the influence of certain conditioning factors. Mendoza (1987) mentions that adoption is an individual decision based on factors of knowledge, availability of resources, skills and the willingness of the producer to change partially or totally his traditional form of production.

That means that the comparative advantage of a region in the production of a crop is not only given by its favorable supply of natural resources such as land or climate, but also depends on the adoption of innovations in agricultural technologies (Khonje, Manda, Arega, \& Kassie, 2015). In this context, it can be said that efforts have been made to identify the factors that restrict or influence the adoption of agricultural technologies and their competitiveness. indispensable en la rentabilidad y competitividad del sector (Seixas \& Ardila, 2002), específicamente para los pequeños productores que se ven inmersos en un mercado cada vez más competitivo a escala global, así como entre industrias y países (Williams, 2007).

Las investigaciones sobre competitividad constituyen una amplia literatura, compuesta tanto de estudios teóricos como empíricos (Lambrecht, Vanlaue, Merckx, \& Maertens, 2014). En los segundos, a nivel micro se ha demostrado que la intensificación agrícola a través de la difusión y la adopción de mejor tecnología contribuye a reducir la pobreza y la inseguridad alimentaria (Shiferaw, Kebede, \& You, 2008; Kijima, Otsuka, \& Sserukuuma, 2008). La mayoría de estos estudios se realizaron en países en desarrollo enfocándose a las características socioeconómicas de la unidad de producción, como la disponibilidad de capital o las restricciones crediticias entre otras (Zeller, Diagne, \& Mataya, 1998). Otros estudios se han enfocado en una tecnología específica y en la secuencia de pasos que componen la adopción de los elementos de un paquete tecnológico (Aldana, Foltz, Barham, \& Useche, 2011; Byerlee \& de Polanco, 1986).

Ramírez (1999), al evaluar la tecnología para el maíz recomendada por el "Plan Llanos de Serdán" en el oriente del estado de Puebla, definió la adopción de tecnología como el uso adecuado de nuevas tecnologías agrícolas para mejorar el manejo del cultivo y aumentar los rendimientos por hectárea; también es la forma de cómo los productores combinan los factores de la producción en cada una de las prácticas agrícolas y la productividad de los factores se expresa en los rendimientos por hectárea (Damian-Huato, et al., 2009). Galindo (2004) establece que la adopción de tecnología es un proceso mental, en el que los campesinos después de tener información por primera vez acerca de una innovación pasan a la decisión de aceptarla o rechazarla bajo la influencia de ciertos factores condicionantes. Por su parte Mendoza (1987) menciona que la adopción es una decisión individual que está en función de factores de conocimiento, disponibilidad de recursos, destrezas y, de la disposición del productor de cambiar parcial o totalmente su forma tradicional de producción.

Eso significa que la ventaja comparativa de una región en la producción de un cultivo no solo está 
Solow (1979) mentions that the population has a decreasing trend to the extent that labor is being replaced by technologies and that the final good is produced only with technology; it is technological progress that increases labor productivity and grows at a constant rate.

In smallholder agriculture, technological adoption has limitations, and in turn the factors that promote it, with most related to the peasant. Some studies do not take into account cognitive characteristics and psycho-social factors, which can influence peasants, in addition to the opinion of other people (Martínez, Dorward, \& Rehman, 2012). Harwood (1979) notes that, in similar crops and production practices, the reaction of small farmers to change varies due to differences in attitude and capacity, among other factors. For Posada (1995), the adoption of technology is related to the cultural history of the producer. Turijan, Ramírez, Damián, Juárez, and Estrella (2015) state that adoption will depend on how culturally appropriate the technology is, whether it is necessary and in accordance with one's own interests, whether it is respectful of traditions, whether it is useful, whether it achieves good results in the short term, and whether it does not exhibit financial risks.

It can be said that technological adoption does not take place due to the lack of: a) technologies appropriate to the socio-cultural characteristics of the farmer, b) government programs for dissemination and transfer of technology (Galindo, 1996). The adoption of technology should consider the experience of farmers who constantly improve the way they manage their crops. Changes in natural conditions, resource availability and market development also need to be taken into account, as they directly influence technological adoption (CIMMYT, 1993). It is necessary to consider the weather because of the uncertainty represented by not knowing when and how often it will rain (Blanco, 1980). The availability and price of the recommended inputs must be reasonable, the advice given by disseminators on the agricultural process must be timely and there must be markets where the product can be sold (Díaz, Jiménez, Carrillo, González, \& Valseca, 1991). It can be said that adoption among peasants is subject to diverse circumstances and dada por su favorable dotación de recursos naturales como la tierra o el clima, también depende de la adopción de innovaciones en tecnologías agrícolas (Khonje, Manda, Arega, \& Kassie, 2015). En este contexto, se puede decir que los esfuerzos se han encaminado a identificar cuáles son los factores que restringen o influyen en la adopción de tecnologías agrícolas y su competitividad. Solow (1979) menciona que la población tiene una tendencia decreciente en la medida que la mano de obra va siendo sustituida por tecnologías y que el único bien final se produce solo con tecnología, es el progreso tecnológico que aumenta la productividad del trabajo y crece a una tasa constante.

En la agricultura minifundista la adopción tecnológica tiene limitantes, y a su vez factores que la promueven y, la mayoría están relacionadas con el campesino. En algunas investigaciones no toman en cuenta las características cognitivas y los factores psico-sociales, que pueden influir en los campesinos, además de la opinión de otras personas (Martínez, Dorward, \& Rehman, 2012). Harwood (1979) menciona que, en cultivos y prácticas de producción similares, la reacción de los pequeños agricultores al cambio varía debido a las diferencias de actitud y capacidad, entre otros factores. Para Posada (1995) la adopción de tecnología está relacionada con la historia cultural del productor. Turijan, Ramírez, Damián, Juárez, y Estrella (2015) mencionan que la adopción dependerá de qué tan apropiada culturalmente sea la tecnología, si es necesaria y si está de acuerdo con los propios intereses, si es respetuosa con las tradiciones, si es útil, si obtiene buenos resultados a corto plazo y si no exhibe riesgos financieros.

Se puede afirmar que la apropiación tecnológica no se lleva a cabo por la inexistencia de: a) tecnologías apropiadas a las características socioculturales del agricultor, b) por la falta de programas gubernamentales de difusión y transferencia de tecnología (Galindo, 1996). En la adopción de tecnología se debe considerar la experiencia de los agricultores que constantemente perfeccionan la forma en que manejan sus cultivos. También es necesario tomar en cuenta los cambios de las condiciones naturales, la disponibilidad de recursos y el desarrollo de los mercados, ya que influyen 
factors and encompasses a complex series of elements depending on the production process of the crop in which they are employed; it is also a function of the environmental, socio-cultural and economic characteristics of the farmers, in such a way that they can be found or made visible in the construction of irrigation systems, as well as the purchase of machinery and inputs.

Juárez and Ramírez (2008) consider that it is not easy for small peasants to increase their production levels, due to the scarcity of resources and technologies adapted to their needs, and due to their lower economic capital, which becomes a limiting factor in the adoption of technology. In this sense, peasants will only be willing to adopt them if the new techniques ensure an adequate economic return. Ruttan and Hayami (1989) argue that if a factor becomes more expensive, peasants will express a tendency to reduce the use of that factor. This is where peasants generate strategies to reduce the cost of production factors. In this sense, Juarez and Ramírez (2008) mention that the adoption of technology will depend on the price of inputs, since increasing yields will not compensate for the investment made if the product does not have an adequate price. Although there are government programs for the transfer of economic resources to smallholder producers, these are of a welfare nature and provide them with scarce resources for production.

\section{Method}

The research was conducted in the municipalities of Tlachichuca and Chalchicomula de Sesma $\left(97^{\circ} 25^{\prime} 09^{\prime \prime}\right.$ $\left.\mathrm{W}, 18^{\circ} 59^{\prime} 20^{\prime \prime} \mathrm{N}\right)$, located in the central-eastern part of the state of Puebla (Figure 1). The study area covers $811 \mathrm{~km}^{2}$, with an elevation of $2562 \mathrm{~m}$ and a total population of 72450 inhabitants. The Labor Force Participation Rate (LFPR) was $43.2 \%$, its average schooling is 6.7 years, the illiterate population amounts to $13.9 \%$, its main economic activity is agriculture, to which 14919.74 ha are allocated (SAGARPA, 2014), and the crop that occupies the largest area is maize produced under rainfed conditions. The municipalities have an average degree of marginalization (SEDESOL, 2012). The PROAGRO and PROSPERA Programa de Inclusion directamente en la adopción tecnológica (CIMMYT, 1993). Se debe tomar en cuenta el temporal por la incertidumbreque representa el no saber cuándoy con qué frecuencia lloverá (Blanco, 1980). La disposición y el precio de los insumos recomendados tienen que ser razonables; y la asesoría tiene que ser oportuna por parte de los divulgadores en el proceso agrícola; así como la existencia de mercados donde vender la producción (Díaz, Jiménez, Carrillo, González, \& Valseca, 1991). Se puede decir que la adopción entre los campesinos está sujeta a diversas circunstancias y factores y engloba una serie compleja de elementos dependiendo del proceso de producción del cultivo en que son empleadas; también está en función de las características ambientales, socioculturales y económicas de los agricultores, de tal manera que, se pueden encontrar o hacerse visibles en la construcción de sistemas de riego, adquisición de maquinaria y compra de insumos.

Juárez y Ramírez (2008) consideran que a los pequeños agricultores no les es fácil aumentar sus niveles de producción, debido a la escasez de recursos y tecnologías que se adapten a sus necesidades, y a su reducido capital económico que se convierte en una limitante en la adopción de tecnología. En este sentido, los campesinos solo estarán dispuestos a adoptarlas en caso de que las nuevas técnicas aseguren una adecuada retribución económica. Ruttan y Hayami (1989) argumentan que, si un factor se encarece, los campesinos expresarán una tendencia a la reducción en el uso de ese factor. Es aquí en donde los campesinos generan estrategias para reducir el costo de los factores de la producción. En ese sentido, Juárez y Ramírez (2008) mencionan que la adopción de tecnología va a depender del precio de los insumos, ya que el incrementar los rendimientos no compensará la inversión realizada, si no existe un precio adecuado del producto. $\mathrm{Si}$ bien existen programas gubernamentales de transferencia de recursos económicos a los productores minifundistas, estos son de corte asistencialista al proporcionarles recursos escasos para la producción.

\section{Método}

La investigación se realizó en los municipios de Tlachichuca y Chalchicomula de Sesma ( $97^{\circ} 25^{\prime} 09^{\prime \prime}$ 


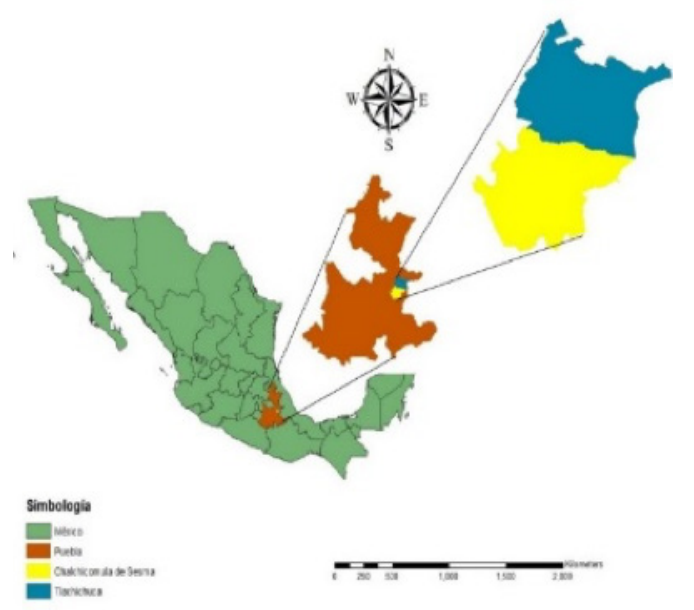

Figura 1. Ubicación del Área de Estudio en el Contexto Nacional y Estatal. Fuente: Elaboración Propia

Social programs operate. In Chalchicomula, the Programa de Insumos Agrícolas PESO a PESO operates, which gives the farmer a maximum of 18 bundles of the fertilizer urea.

In this research a bibliographic review of the concepts of Technology Adoption, Competitiveness and Productivity was carried out. The information was collected through the application of a questionnaire. The fieldwork was carried out from January to March 2015, the unit of study was maize producers and key informants were interviewed. In order to analyze the economic and productive aspects, agrosystems were used (Figure 2), according to Taboada (1996), with the following characteristics: I. Ciudad Serdán. Sandy and deep Cambiosol-type soils of high productive potential, $\mathrm{pH}$ of 6.5 to 7.0 , flat topography. II. Coyotepec. Sandy soils and greater risk of constant frost, high productive potential. III. Tlachichuca. Deep, sandy soils with undulating topography. IV. Low potential. Light colored, deep, coarse textured soils with $\mathrm{pH}$ from 7.5 to 8.5. High frequency of frost, drought and strong winds. v. Sierra. Unimportant in maize production.

To determine the size of the sample, Simple Random Sampling was used, and the sampling frame was the PROAGRO standard, with a total of 6 868 beneficiaries. Precision was estimated with the yield variable $(750 \mathrm{~kg})$ being $25 \%$ of the average production recorded in the selected municipalities (3.15 tha ${ }^{-1}$ ) and reliability was $95 \%$. The sample

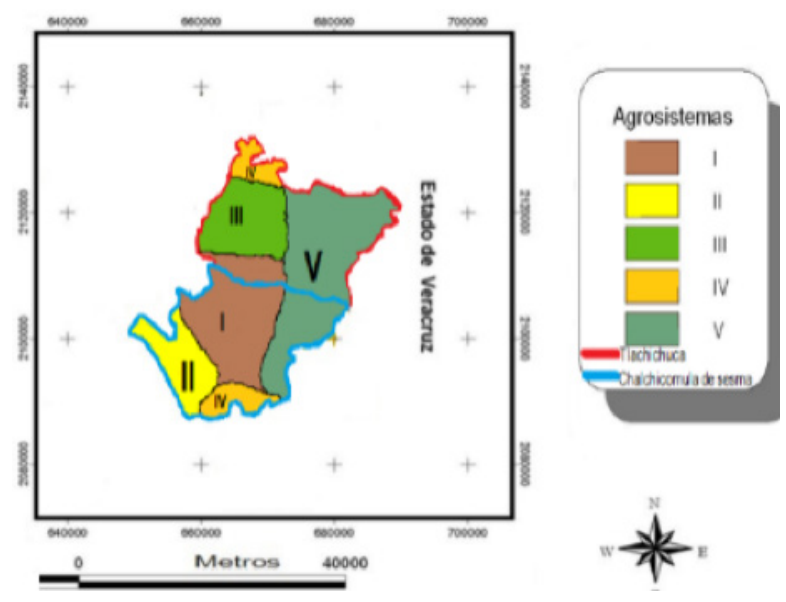

Figura 2. Agrositemas en los municipios de Tlachichuca y Chalchicomula de Sesma.

Fuente: elaboración propia. Datos Taboada 1996

LO, $\left.18^{\circ} 59^{\prime} 20^{\prime \prime} \mathrm{LN}\right)$, localizados en el centro-oriente del estado de Puebla (Figura 1). El área de estudio tiene una extensión de $811 \mathrm{~km}^{2}$, una altitud de 2562 m y una población total de 72450 habitantes, la Tasa de Participación Económica (TPE) fue de $43.2 \%$, su escolaridad promedio es de 6.7 años, la población analfabeta asciende a $13.9 \%$, su principal actividad económica es la agricultura, a la cual se destinan 14 919.74 ha (SAGARPA, 2014) y el sistema que ocupa la mayor superficie es el maíz producido bajo condiciones de temporal. Los municipios tienen un grado medio de marginación (SEDESOL, 2012). Operan los programas PROAGRO y PROSPERA Programa de Inclusión Social. En Chalchicomula opera el Programa de Insumos Agrícolas PESO a PESO, que otorga al campesino un máximo de 18 bultos de urea.

En esta investigación se realizó una revisión bibliográfica de los conceptos de Adopción de Tecnología, Competitividad y Productividad. En la recopilación de la información se recurrió a la técnica del cuestionario. El trabajo de campo se realizó en los meses de enero a marzo de 2015, la unidad de estudio fueron los agricultores de maíz y se realizaron entrevistas a informantes clave. Para analizar los aspectos económicos y productivos se emplearon los agrosistemas (Figura 2), de acuerdo con Taboada (1996), presentan las siguientes características: I. Ciudad Serdán. Suelos arenosos y profundos, topografía plana y un pH de 6.5 a 7.0 tipo Cambrisol, 
size was 79.6 producers and $25 \%$ was added to the sample size for safety, putting the sample at 95 peasants. Through the policy analysis matrix, competitiveness per farmer was calculated at market prices. All those producers who had a profit at the end of the cycle were considered competitive. In order to determine the relationship between competitiveness and socio-demographic variables, the logistic regression method (Wald, forward) was used, which made it possible to select from each of the variables that which had the greatest weight in terms of competitiveness, using the following model:

$\ln \left(\frac{p}{(1-p)}\right)=\beta_{0}+\beta_{1} x_{1+\ldots} \beta_{n} x_{n}$

Where:

$p=\pi\left(Y=\frac{1}{x}\right)$ is the probability that the response variable $(Y)$ acquires the value of $\beta_{0^{\prime}} \beta_{1^{\prime}} \beta_{n}$ are unknown parameters and $x_{1}, x_{\mathrm{n}}$ are exploratory variables. Therefore, the probability can be obtained in the following way:

$p=\frac{\theta^{\beta_{0}+\beta_{1} x_{1}+\cdots \beta_{n} x_{n}}}{1+\theta^{\beta_{0}+\beta_{1} x_{1+\cdots}+\cdots \beta_{n} x_{n}}}$

In order to determine the level of technology adoption, the following was applied: 1) Formal Tech Adoption Index (FTAI) proposed by Damián et al. (2012), which identifies the level at which maize growers used technologies generated and recommendations by Plan and 2) the Level of Employment of Peasant Technologies (LEPT), which measures, on a scale from 0 to 100 , the level at which producers used locally generated technologies, proposed by the same authors.

\section{Use of Modern Technology in Maize Production}

The average age of the interviewees was 57.7 years old. When classifying them by agrosystem, no statistical difference was found $(F=1.187 ; P=0.322)$ between them, meaning that the peasants are statistically the same age. However, they are older compared to the independent workers in the agricultural sector on a national scale (49.6 years old) according to the National Household Income and Expense Survey $(E N I G H, 2012)$ and is similar $(t=-1.089$; $P=0.05$ ) to that of the ejidatarios of the country, who de alto potencial productivo. II. Coyotepec. Suelos arenosos y mayor riesgo de heladas constantes, alto potencial productivo. III. Tlachichuca. Suelos arenosos, profundos y con topografía ondulada. IV. Bajo potencial. Suelos de textura gruesa, de color claro, profundos, con pH de 7.5 a 8.5. Alta frecuencia de heladas, sequía y vientos fuertes. V. Sierra, no es importante en la producción de maíz.

Para determinar el tamaño de la muestra se utilizó el Muestreo Simple Aleatorio y el marco de muestreo fue el padrón del PROAGRO, con un total de 6868 beneficiados. La precisión se estimó con la variable rendimiento $(750 \mathrm{~kg})$ siendo el $25 \%$ de la producción promedio registrada en los municipios seleccionados (3.15 t.ha ${ }^{-1}$ ) y la confiabilidad fue del $95 \%$. El tamaño de muestra fue de 79.6 productores y se agregó $25 \%$ al tamaño de la muestra por seguridad, quedando la muestra en 95 agricultores. A través de la matriz de análisis de políticas se calculó la competitividad por agricultor a precios de mercado. Se consideraron competitivos a todos aquellos productores que tuvieran ganancia al final de ciclo. Para determinar la relación entre la competitividad y las variables sociodemográficas se utilizó el método de regresión logística (Wald, hacia adelante), el cual permitió seleccionar de cada una de las variables cuáles tenían más peso en cuanto a la Competitividad, mediante el siguiente modelo:

$\ln \left(\frac{p}{(1-p)}\right)=\beta_{0}+\beta_{1} x_{1+\ldots} \beta_{n} x_{n}$

Donde:

$p=\pi\left(Y=\frac{1}{x}\right)$ es la probabilidad de que la variable respuesta ( $\mathrm{Y}$ ) adquiera el valor de $\beta_{0^{\prime}} \beta_{1^{\prime}} \beta_{\mathrm{n}}$ son parámetros desconocidos y $x_{1}, x_{n}$ son variables exploratorias. Por lo que la probabilidad puede ser obtenida de la siguiente manera: .

$p=\frac{\theta^{\beta_{0}+\beta_{1} x_{1+\cdots} \beta_{n} x_{n}}}{1+\theta^{\beta_{0}+\beta_{1} x_{1+\cdots} \ldots \beta_{n} x_{n}}}$

Para determinar el grado de adopción de tecnología se aplicó: 1) Índice de Apropiación de Tecnologías Formales (IATF) propuesto por Damián et al. (2012), que identifica el grado en que los maiceros usaron tecnologías generadas y recomendaciones por Plan y 2) el Grado de Empleo 
average 60 years old (SEDATU, 2012). This indicates that a good proportion of the population working in the countryside are older people. Peasants have an average schooling of 6.3 years. In the Tlachichuca agrosystem its producers had the highest schooling (6.7 years), and the producers with the lowest years of study (6.2 years) were located in the Serdán and Sierra agrosystems. The producers interviewed have a lower level of education than the national average (8.6 years) and the state of Puebla (8.0 years) (INEGI, 2010a). A negative correlation was found between age and schooling of producers $(r=-0.44 ; P<0.001)$, which indicates that the older they are, the lower their level of schooling.

All the interviewees mentioned that they own rainfed land, with ejido ownership predominating (93.7 \%), with an average area of 7.4 ha. The Serdán agrosystem had the largest average area ( $8.4 \mathrm{ha})$ and the Coyotepec agrosystem was characterized by having the smallest average area (5.6 ha); although there are extreme values in the area per agrosystem, no significant statistical difference was found ( $F=1.291 ; P=0.282$ ). It was also detected that, through time, statistically $(\mathrm{t}=-1.873 ; P=0.064)$ the interviewees continue having the same land endowment with respect to the one assigned to them in the agrarian distribution ( 8.5 ha). According to the characteristics of the peasants interviewed, it can be said that they are smallholder producers; in this sense, Altieri (2009), when referring to food production, highlights the importance of this type of peasant in food production.

With respect to the use of technologies in the maize production process, agricultural machinery and the application of agrochemicals stand out. As for the former, the tractor is a fundamental piece of equipment for soil preparation. In this process, a fallow and two harrow steps were recommended for agrosystems I and II, and a fallow and a harrow step for agrosystems III and V. Fallow and harrow work was carried out by all the producers interviewed, with $86.3 \%$ using the tractor on the fallow. There are authors such as Pearson (2003) and Ramírez, Ramírez, Juárez, \& Cesin (2007) who point out that the greater frequency in the use of the tractor is due to the difficulty of fallow and that it reduces time, which makes a tractor a very useful piece of and most peasants choose to carry de Tecnologías Campesinas (GETC), que mide en una escala de 0 a 100, el nivel en que los productores utilizaron tecnologías generadas localmente, propuesto por los mismos autores.

Uso de tecnología moderna en la producción de Maíz

La edad promedio de los entrevistados fue de 57.7 años, al clasificarlos por agrosistema, no se encontró diferencia estadística ( $\mathrm{F}=1.187 ; P=0.322)$ entre estos, significa que los agricultores estadísticamente tienen la misma edad. Sin embargo, es mayor a la que presentan los trabajadores independientes del sector agropecuario a escala nacional (49.6 años) de acuerdo con la Encuesta Nacional de Ingreso y Gastos de los Hogares (ENIGH, 2012) y es similar $(\mathrm{t}=-1.089 ; P=0.05)$ a la de los ejidatarios del país -60 años- (SEDATU, 2012). Esto indica que una buena proporción de la población que se encuentra laborando en el campo son personas mayores. Los agricultores tienen una escolaridad promedio de 6.3 años. En el agrosistema Tlachichuca sus productores tuvieron la mayor escolaridad (6.7 años), y los productores con menores años de estudio (6.2 años) se ubicaron en el agrosistema Serdán y Sierra. Los productores entrevistados poseen un menor nivel educativo con respecto al promedio nacional (8.6 años) y del estado Puebla (8.0 años) (INEGI, 2010a). Se encontró una correlación negativa entre la edad y la escolaridad de los productores ( $r=-0.44$; $P<0.001)$ que indica que, a mayor edad, menor nivel de escolaridad.

Los entrevistados en su totalidad mencionaron que poseen tierras de temporal, predominando la propiedad ejidal (93.7\%), con una superficie promedio de 7.4 ha. El agrosistema Serdán tuvo la mayor superficie promedio ( $8.4 \mathrm{ha}$ ) y el agrosistema Coyotepec se caracterizó por poseer la menor superficie promedio (5.6 ha); a pesar de que hay valores extremos en la superficie por agrosistema, no se encontró diferencia estadística significativa $(\mathrm{F}=1.291 ; P=0.282)$. También se detectó que, a través del tiempo, estadísticamente $(t=-1.873 ; P=0.064)$ los entrevistados siguen teniendo la misma dotación de tierras con respecto a la que se les asignó en el reparto agrario (8.5 ha). De acuerdo con las características de los agricultores entrevistados se puede decir que son productores de corte minifundista, en ese 
out the work with such equipment. A total of $60 \%$ performed the work with a rented tractor and as for those who used a yoke this was usually their own.

In the method used in this study, there was no significant statistical difference found by the Kruskal Wallis test (Chi-square $=2.718 ; \quad P=0.257$ ) among agrosystems, which means that the method of carrying out activities in all agrosystems is the tractor, mainly in land preparation. In the Tlachichuca (87.5\%) and Serdán (90\%) agrosystems, it was a little more common to use the tractor and it was a little lower in Sierra (86.4 \%) and Coyotepec (78.9\%).

As for improved seeds, their use in agrosystems was minimal; in Tlachichuca, one interviewee used the variety VS-22 at a price of $\$ 1200.0$ per package with 50 thousand seeds. Turijan et al. (2015) mention that the use of improved seeds not only requires significant expenses in their purchase, but also of inputs to guarantee their optimal development, which contributes to the fact that few producers have access to them. Also, their low use responds to the fact that criolla (native) seeds have good yields, and in most cases better than hybrids in the same conditions; in fieldwork, yields of up to 8 tons per hectare were found, which agrees with the average yields found by Aceves et al. (1993); Turrent et al. (1994); Regalado et al. (1996), but by adopting agricultural technology, including improved seeds.

With respect to the population density of the crop, the Plan Llanos de Serdán recommends 45 thousand plants per hectare for agrosystem I and II and for III and V it advises 40 thousand-plants.ha ${ }^{-1}$ (Juárez \& Ramírez-Valverde, 2008). It should be noted that, at this point, the density obtained exceeded that recommended in the technological package of the Colegio de Postgraduados, and indicates that the population density increased at the time of sowing. The Ciudad Serdán agrosystem recorded an average population density of 66099.1 plants per hectare, the Coyotepec agrosystem 59 241.4, and the Tlachichuca agrosystem 69 936.2, which had the highest population density, whereas the Sierra agrosystem had the lowest density (58 859.8).

The interviewees carried out 3 tasks on their land to control weeds, through cultivation practices that are known locally as: "tumba de bordo, cerrada de labor y segundada. Contrary to the fallow, where the sentido, Altieri (2009) al referirse a la producción de alimentos, destaca la importancia de este tipo de agricultores en la producción de alimentos.

Con respecto al uso de tecnologías en el proceso productivo del maíz, destaca la maquinaria agrícola y la aplicación de agroquímicos. En cuanto a la primera, el tractor es un equipo fundamental en la preparación del suelo. En este proceso, se recomendó un barbecho y dos pasos de rastra para los agrosistemas I y II, un barbecho y un paso de rastra para los agrosistemas III y V. Las labores de barbecho y dobla fueron realizadas por la totalidad de los productores entrevistados, el 86.3 \% utilizó el tractor en el barbecho, hay autores como Pearson, (2003); Ramírez, Ramírea, Juárez, \& Cesin, (2007) quienes señalan que la mayor frecuencia en el uso del tractor, se debe a la dificultad que lleva el barbecho y que en su realización reduce tiempo, por lo que lo hace una maquinaria muy conveniente y la mayoría de los campesinos optan realizar la labor con dicho equipo. El 60 \% realizó las labores con tractor alquilado y en cuanto a los que utilizaron yunta esta fue fundamentalmente propia.

En el método empleado en las labores, no existió diferencia estadística significativa arrojada por la prueba de Kruskal Wallis (Chi- cuadrado=2.718; $P=0.257$ ) entre agrosistemas, lo que significa que el método de realización de las actividades en todos los agrosistemas es el tractor, principalmente en la preparación de los terrenos. En los agrosistemas Tlachichuca (87.5 \%) y Serdán (90\%) fue un poco más común utilizar el tractor y fue un poco menor en la Sierra (86.4 \%) y Coyotepec (78.9 \%).

En cuanto a las semillas mejoradas su empleo en los agrosistemas fue mínimo, en Tlachichuca un entrevistado empleó la variedad VS-22 a un precio de $\$ 1200.0$ el bulto con 50 mil semillas. Turijan, et al. (2015) mencionan que el uso de semillas mejoradas no solo requiere gastos importantes en su compra, sino que también de insumos para garantizar su óptimo desarrollo, lo cual contribuye a que unos cuantos productores accedan a ellas. También su bajo uso responde a que las semillas criollas exhiben buenos rendimientos, y en algunos casos mejores que los híbridos en las mismas condiciones; en trabajo de campo se encontraron rendimientos de hasta 8 toneladas por hectárea, que concuerda con 
use of the tractor stood out, here the interviewees mainly used the yoke (93.7\%); of this percentage, $54.4 \%$ stressed that its use is cheaper than renting a tractor, $40.4 \%$ said that it is more affordable and practical than using a tractor, due to not compacting the soil and better controlling weeds, and $5.2 \%$ said they had no other alternative. The tendency for this method can be explained by the fact that producers use their own animals for less laborious practices, secondary tillage, sowing, weeding and harvesting (Turijam, 2012). Also, the peasant has more experience in carrying out these practices which makes him have better management of herbs, and that reduces the cost of handling them.

On the other hand, no statistical difference was found in the Kruskal Wallis test where: (ChiSquare $=1.315$ and $P=0.518$ ) among the agrosystems in the method of carrying out the activities, by which it is inferred they mainly used a yoke; this can be attributed to the small area they own, to the quality of the activity and to the cost of using a tractor.

In fertilization, all interviewees used chemical fertilizer, especially urea (46-00-00) and 18-1600 ; on average they applied 127.2 of nitrogen, $31.9 \mathrm{~kg}$ of phosphorus and $00 \mathrm{~kg}$ of potassium (NPK). Fertilization by agrosystem according to the technological package of the Plan Llanos de Serdán of the Colegio de Postgraduados recommends for agrosystems I and II, which are those showing greater productive potential, for limited capital, a fertilization dose of $110 \mathrm{~kg}$ of nitrogen and 130 for producers with a greater level of capitalization; it is also recommended to apply 50 kilos of phosphorus per hectare (Juárez \& Ramírez, 2008). In Agrosystems III and V, it is recommended to apply $80 \mathrm{~kg}$ of nitrogen for peasants with limited capital and $100 \mathrm{~kg}$ for those whose resources are greater and with respect to phosphorus an amount of $40 \mathrm{~kg}$ per hectare is recommended (Juárez \& Ramírez, 2008).

In the Serdán (123-28-00) and Coyotepec (13021-00) agrosystems, they fertilized with nitrogen according to the recommended dose, both for limited and unlimited capital; by not finding a statistical difference (Table 1), it can be inferred that the amount applied was the appropriate one. However, for the variable phosphorus, it was found that the amount used was not as recommended (Table 1). For los rendimientos medios encontrados por Aceves, et al. (1993); Turrent et al. (1994); Regalado et al. (1996), pero adoptando tecnología agrícola entre ellas, las semillas mejoradas.

Con respecto a la densidad de población del cultivo, el Plan Llanos de Serdán recomienda 45 mil plantas por hectárea para el agrosistema I y ll y para el III y V aconseja 40 mil-plantas.ha ${ }^{-1}$ (Juárez \& RamírezValverde, 2008). Cabe destacar que, en este punto, la densidad obtenida superó a la recomendada en el paquete tecnológico del Colegio de Postgraduados, e indica que, en la siembra se aumentó la densidad de población. El agrosistema Ciudad Serdán registró una densidad media poblacional de 66099.1 plantas por hectárea, el agrosistema de Coyotepec 59 241.4, el agrosistema Tlachichuca 69936.2 -este tuvo mayor densidad de población- y el agrosistema de la Sierra presentó la menor densidad (58 859.8).

Los entrevistados realizaron 3 labores a sus terrenos para controlar las malezas, mediante las prácticas de cultivo que son conocidas localmente como: "tumba de bordo, cerrada de labor y segundada". Al contrario del barbecho del suelo en donde destacó el uso del tractor, aquí los entrevistados utilizaron fundamentalmente la yunta (93.7\%), de este porcentaje, el $54.4 \%$ destacó que su uso es más económico que rentar un tractor, el $40.4 \%$ dijo que es más asequible y práctico que el emplear el tractor, al no compactar el suelo y controlan mejor las malezas, y el $5.2 \%$ destacó no tener otra alternativa. La tendencia por este método puede explicarse debido a que los productores utilizan sus propios animales para prácticas menos laboriosas -labranzas secundarias, siembra, deshierbes y cosecha- (Turijam, 2012). Asimismo, el agricultor cuenta con mayor experiencia en la realización de estas prácticas lo cual hace que tenga un mejor manejo de las hierbas, y eso reduce el costo de manejarlas.

Por otra parte, no se encontró diferencia estadística en la prueba de Kruskal Wallis donde: (ChiCuadrada $=1.315$ y $P=0.518$ ) entre los agrosistemas en el método de realización de las labores, por lo cual se infiere emplearon fundamentalmente la yunta, esto puede atribuirse a la pequeña superficie que poseen, a la calidad del trabajo y al costo que tiene utilizar el tractor. 
Table 1. Table of $\mathrm{T}$ tests for fertilization dose by agrosystem.

Cuadro 1. Tabla de pruebas de T para dosis de fertilización por agrosistema.

\begin{tabular}{|c|c|c|c|c|c|c|c|c|}
\hline \multirow{3}{*}{$\begin{array}{l}\text { Agrosystem / } \\
\text { Agrosistema }\end{array}$} & \multicolumn{4}{|c|}{$\begin{array}{l}\text { Unlimited Resources / } \\
\text { Recursos Ilimitados }\end{array}$} & \multicolumn{4}{|c|}{$\begin{array}{l}\text { Limited Resources / } \\
\text { Recursos Limitados }\end{array}$} \\
\hline & \multicolumn{2}{|c|}{ Nitrogen / Nitrógeno } & \multicolumn{2}{|c|}{ Phosphorus / Fósforo } & \multicolumn{2}{|c|}{ Nitrogen / Nitrógeno } & \multicolumn{2}{|c|}{ Phosphorus / Fósforo } \\
\hline & $t$ & $p$ & $t$ & $p$ & $t$ & $p$ & $t$ & $p$ \\
\hline Serdán & -0.838 & 0.409 & -2.27 & 0.031 & 1.567 & 0.128 & -2.27 & 0.031 \\
\hline Coyotepec & 0.069 & 0.946 & -2.214 & 0.04 & 1.811 & 0.087 & -1.429 & 0.170 \\
\hline Tlachichuca & 3.571 & 0.002 & -2.191 & 0.039 & 5.89 & 0.001 & -0.684 & 0.501 \\
\hline Sierra & 5.963 & 0.001 & -0.818 & 0.422 & 10.527 & 0.001 & 0.182 & 0.857 \\
\hline
\end{tabular}

Source: Compilation by the author

Fuente: Elaboración Propia.

the Tlachichuca agrosystem, they fertilized using the dose 130-35-00 and in the Sierra the dose 126-41-00. With respect to the adoption of fertilizer by limited capital of nitrogen, it was found that they applied greater amounts than the recommended level (Table 1), that is, they did not apply the appropriate dose. Phosphorus was applied properly, as the $t$ test did not show significant statistical difference to determine that the amounts were not in accordance with the recommendation. For agrosystem three corresponding to Tlachichuca, $40 \mathrm{~kg}$ of phosphorus is statistically recommended (Table 1 ). It was found that the quantities applied were not in accordance with the recommendations for limited capital, but for unlimited capital there was no difference $(-2.191$, $P=0.039$ ). Peasants are often unable to adopt the technology because of the cost it implies (Juárez et al., 2009 and Damián et al., 2008) and the high risk.

Regarding the Formal Tech Adoption Index (FTAI) proposed by Damián et al. (2012) that identifies the level at which maize growers used the technologies generated and recommended by the Instituto Nacional de Investigaciones Forestales, Agrícolas y Pecuarias (INIFAP), when comparing both practices, no data were found on soil conservation activities or pest and disease control practices. They are not controlled in the region because the cost is high. The following IATF distribution was found: Serdán 51.2, Coyotepec 49.3, Tlachichuca 53.6, and Sierra 53.6; highlighting the last two agrosystems with the highest index, this result accredits them as medium producers in the
En la fertilización la totalidad de los entrevistados utilizaron abono químico destacando la urea (4600-00) y el 18-16-00, en promedio aplicaron 127.2 de nitrógeno, 31.9 fósforo y 00 de potasio (NPK). La fertilización por agrosistema de acuerdo al paquete tecnológico del Plan Llanos de Serdán del Colegio de Postgraduados recomienda para los agrosistemas I y II, que son los que presentan un mayor potencial productivo, para capital limitado, una dosis de fertilización de $110 \mathrm{~kg}$ de nitrógeno y 130 para productores con mayor nivel de capitalización; y recomiendan aplicar 50 kilos de fósforo por hectárea (Juárez \& Ramírez, 2008). En los Agrosistemas III y $\mathrm{V}$, se recomiendan aplicar $80 \mathrm{~kg}$ de nitrógeno para agricultores con capital limitado y, $100 \mathrm{~kg}$ para aquellos cuyos recursos son mayores y con respecto al fósforo se recomienda una cantidad de $40 \mathrm{~kg}$ por hectárea (Juárez \& Ramírez, 2008).

En el agrosistema Serdán (123-28-00) y Coyotepec (130-21-00) fertilizaron con nitrógeno de acuerdo con la dosis recomendada, tanto para capital limitado como ilimitado, al no encontrar diferencia estadística (Cuadro 1) por lo que se infiere a la cantidad aplicada, fue la apropiada. Sin embargo, para la variable fósforo, se encontró evidencia que la cantidad empleada no fue la recomendada (Cuadro 1). Para el agrosistema Tlachichuca, fertilizaron empleando la dosis 130-35-00 y en la Sierra la dosis 126-41-00. Con respecto a la adopción de fertilizante por capital limitado de nitrógeno se encontró que aplicaron cantidades mayores a las recomendadas (Cuadro 1), 
Table 2. Percentage of technology adoption compared to the recommendations of the Plan Llanos de Serdán per hectare.

Cuadro 2. Porcentaje de Adopción de tecnología comparada con las recomendaciones del Plan Llanos de Serdán por hectárea.

\begin{tabular}{|c|c|c|c|c|c|c|}
\hline $\begin{array}{l}\text { Agrosystem / } \\
\text { Agrosistema }\end{array}$ & $\begin{array}{c}\text { Land } \\
\text { preparation / } \\
\text { Preparación del } \\
\text { terreno }\end{array}$ & $\begin{array}{l}\text { Population } \\
\text { Density / } \\
\text { Densidad de } \\
\text { Población }\end{array}$ & $\begin{array}{l}\text { Fertilization } \\
\text { Dose / } \\
\text { Dosis de } \\
\text { Fertilización }\end{array}$ & $\begin{array}{c}\text { Weed } \\
\text { Control / } \\
\text { Control de } \\
\text { malezas }\end{array}$ & $\begin{array}{l}\text { Adoption } \\
\text { rate / } \\
\text { Promedio de } \\
\text { Adopción }\end{array}$ & $\begin{array}{c}\text { Yield } \\
\text { t.ha-1/ } \\
\text { Rendimiento } \\
\text { t.ha }{ }^{-1}\end{array}$ \\
\hline Serdán & 97.09 & 128.65 & 0.69 & 99.27 & 81.43 & 3.04 \\
\hline Coyotepec & 95.38 & 124.73 & 0.54 & 99 & 79.98 & 2.85 \\
\hline Tlachichuca & 98.24 & 135.25 & 0.89 & 100 & 83.59 & 3.54 \\
\hline Sierra & 97.15 & 127.91 & 0.77 & 98.94 & 81.19 & 3.73 \\
\hline
\end{tabular}

Source: Compilation based on data from the survey of 2015.

Fuente: Elaboración propia a partir de los datos de la encuesta 2015.

typology presented by Turiján et al. (2012). The Level of Employment of Peasant Technologies (LEPT) (Damián et al., 2010), which measures on a scale from 0 to 100 the level at which the producers used technologies generated locally depending on their use, had values from 0 to 20 . The following variables were the weighted ones: sowing with a shovel, use of criolla seed, activities carried out with a yoke (weed control), application of organic fertilizer, crop rotation; this was an indicator that turned out to be slightly higher, although it continued being medium; on average a level of 62.5 was obtained for the defined agrosystems.

By agrosystem, the LEPT was 60.8 for Tlachichuca, 61.0 for Coyotepec, 62,0 for Serdán, and 66.6 for Sierra. These results are similar to those found by Turiján et al. (2015) and the use of this peasant technology highlights the multiple benefits it can provide, such as: increasing yields, diversifying the agroecosystem, reducing weed, pest and disease problems, increasing organic matter and nutrient content, reducing soil erosion, maintaining soil sustainability and providing low-cost technologies for producers (Bolton et al., 2004; Altieri \& Nicholls, 2007). On the other hand, no differences were found between the LEPTs per agrosystem ( $F=6.491 ; P=0.241)$. Likewise, a negative correlation was observed between schooling and the LEPT ( $r=-0.171 ; P=0.098)$, which means that there is no relationship between schooling and the use of peasant agricultural technology. It was also found that age and technology are not correlated IATF. ( $r=-$ $0.038 P=0.715)$. es decir que no aplicaron la dosis adecuada. El fósforo, lo aplicaron adecuadamente, la prueba de t no arrojó diferencia estadística significativa para determinar que las cantidades no fueron acordes a la recomendación. En cuanto al agrosistema tres correspondiente a Tlachichuca, se recomienda $40 \mathrm{~kg}$ de fósforo estadísticamente (Cuadro 1) se encontró que las cantidades aplicadas no fueron acordes a las recomendaciones para capital limitado, pero para capital ilimitado no hubo diferencia (-2.191, $P=0.039)$. Muchas veces los agricultores no pueden adoptar la tecnología por el costo que presupone (Juárez et al., 2009 y Damián et al., 2008) y el alto riesgo.

En cuanto a el Índice de Apropiación de Tecnologías Formales (IATF) propuesto por Damián et al. (2012) que identifica el grado en que los maiceros usaron las tecnologías generadas y recomendadas por el Instituto Nacional de Investigaciones Forestales, Agrícolas y Pecuarias (INIFAP), al comparar ambas prácticas, no se encontraron datos de labores de conservación de suelo y tampoco prácticas para el control de plagas y enfermedades. Ya que en la región no se controlan debido a que el costo resulta un gasto mayor. Se encontró la siguiente distribución del IATF: Serdán 51.2, Coyotepec 49.3, Tlachichuca 53.6, y Sierra 53.6; resaltando los dos últimos agrosistemas con el índice más alto, este resultado los acredita como productores medianos en la tipología emitida por Turiján et al., (2012). El Grado de Empleo de Tecnologías Campesinas (GETC) (Damián et al., 2010) que mide en una escala de 0 a 100 el nivel en que 
The average yield was $3.29 \mathrm{t}^{\mathrm{h}} \mathrm{ha}^{-1}$. The maximum corresponded to the Sierra agrosystem (3.7 th ha $\left.{ }^{-1}\right)$, followed in descending order by the Tlachichuca agrosystem (3.5 t.ha-1), the Ciudad Serdán agrosystem (3.0 t.ha $\left.{ }^{-1}\right)$, and, lastly, the Coyotepec agrosystem with the lowest yield $\left(2.8 \mathrm{t}^{\mathrm{h}} \mathrm{ha}^{-1}\right)$. These yields are considered high when compared with the state yield of $2.133 \mathrm{t}^{\mathrm{h}} \mathrm{ha}^{-1}$ (SIAP, 2014). It was observed that the greater the level of adoption of technologies, the greater the production of maize. A Pearson correlation test was carried out for the fertilization variables ( $\mathrm{N}$ and $\mathrm{P}$ ), with the yield; the result was positive for the applied phosphorus dose $(r=0.034$ and $P=0.744)$ and negative for nitrogen ( $r=-0.040 P=0.703$ ), which indicates that there is no direct relationship between the applied nitrogen dose with respect to the yield per hectare; as for phosphorus, it is not statistically significant.

It can be said that agricultural technology can be improved and thus yield and directly competitiveness, thereby contributing to improving the income and standard of living of maize growers as expressed by Shiferaw et al. (2008); Kijima et al. (2008). This requires studies to generate, transfer and evaluate appropriate technologies.

Rojas (2013) points out that the economic crisis that comes with the neoliberal development model has had a differentiated impact on the agricultural sector, worsening the polarization of the economic and social structure in Mexico, and one of its consequences is migration and its incursion into non-agricultural employment. In this sense, $16.8 \%$ of those interviewed mentioned that they are engaged in non-agricultural activities; of this percentage, $31.3 \%$ are from the Sierra agrosystem and $35 \%$ from Tlachichuca. Statistically $(\mathrm{t}=-1.585$; $P=0.116)$ no difference was found in the yields obtained between those who carried out nonagricultural activities (2.8 th.ha-1) and those who only worked in the field $\left(3.3 \mathrm{t}^{-\mathrm{ha}^{-1}}\right)$, which means that not working in the field full-time did not affect agricultural production too much, largely due to the use of family labor.

For the logistic regression analysis, all the peasants who obtain a positive cost-benefit ratio were considered competitive. There is an $88.2 \%$ chance of success in the result of the competitiveness dependent los productores utilizaron tecnologías generadas localmente en función de su uso, fueron valores de 0 a 20. Siendo las siguientes variables las ponderadas: Siembra con pala, uso de semilla criolla, labores realizadas con yunta (control de malezas), Aplicación de abono orgánico, rotación de cultivos, este fue un indicador que resultó un poco más elevado, aunque siguió siendo medio, en promedio se obtuvo un grado de 62.5 para los agrosistemas definidos. Por agrosistema el GETC fue para Tlachichuca de 60.8, Coyotepec 61.0, Serdán 62.0, y Sierra 66.6. Estos resultados son similares a los encontrados por Turiján et al. (2015) y el uso de esta tecnología campesina destaca los múltiples beneficios como: aumentar el rendimiento, diversificar el agroecosistema, reducir problemas de malezas, plagas y enfermedades, incrementar el contenido de materia orgánica y de nutrientes, disminuir la erosión edáfica, mantener la sustentabilidad de los suelos y son tecnologías de bajo costo para los productores (Bolton et al., 2004; Altieri \& Nicholls, 2007). Por otra parte, no se encontraron diferencias entre los GETC's por agrosistema ( $F=6.491 ; P=0.241)$. Asimismo, se observó una correlación negativa entre la escolaridad y el GETC ( $r=-0.171 ; P=0.098)$, que significa que no existe relación entre la escolaridad y el uso de tecnología agrícola campesina. De la misma manera se encontró que la edad y la tecnología no están correlacionadas IATF. $(r=-0.038 P=0.715)$.

El rendimiento promedio fue de $3.29 \mathrm{t} \cdot \mathrm{ha}^{-1}$, el máximo correspondió al agrosistema sierra (3.7 tha1), en el agrosistema de Tlachichuca obtuvieron 3.5 t.ha-1. Seguido por el de Cd. Serdán $\left(3.0\right.$ t.ha $\left.{ }^{-1}\right)$, y el menor rendimiento lo tuvo el agrosistema Coyotepec

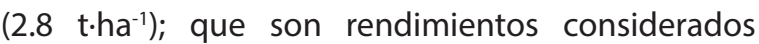
altos al ser comparados con el estatal que es de $2.133 \mathrm{t} \cdot \mathrm{ha}^{-1}$ (SIAP, 2014). Se observó que a mayor grado de adopción de tecnologías mayor producción de maíz. Se realizó una prueba de correlaciones de Pearson para las variables de fertilización ( $\mathrm{N}$ y $\mathrm{P}$ ), con el rendimiento, el resultado fue positivo para la dosis de fósforo aplicado ( $r=0.034$ y $P=0.744$ ) y para el nitrógeno fue negativo ( $r=-0.040 P=0.703)$ lo que indica que no hay una relación directa entre la dosis de nitrógeno aplicada con respecto al rendimiento por hectárea, pero al igual que para el fósforo no es significativa estadísticamente. 
Table 3. Estimation of the logistic regression model with the Wald selection method. Cuadro 3. Estimadores del modelo de regresión logística con el método de selección por pasos hacia adelante (Wald).

\begin{tabular}{cccccc}
\hline Variable & B & E.T. & Wald & P. & Exp(B) \\
\hline $\begin{array}{c}\text { Yield / Rendimiento } \\
\begin{array}{c}\text { Price at which it was sold / } \\
\text { Precio al que vendió }\end{array}\end{array}$ & -4.834 & 2.117 & 5.214 & .022 & .008 \\
Constant / Constante & -3.558 & 1.734 & 4.213 & .040 & .028 \\
\hline
\end{tabular}

Source: Compilation based on data from the 2015 survey.

Fuente: Elaboración propia a partir de los datos de la encuesta 2015.

variable, contributed by the logistic regression. In the calculation of competitiveness through the policy analysis matrix (PAM), $88.4 \%$ of those interviewed were competitive at market prices, so it is assumed that the variables that influenced the model obtained through the logistic regression are those that have more weight in the competitiveness variable.

It can be inferred that agricultural machinery does not have significant effects on productivity and competitiveness. However, selling price is one of the variables that favors or puts competitiveness at a disadvantage, a factor that has already been addressed by Flores, García, Mora and Pérez (2014) and García et al. (2006), that is, a high price makes the producer more competitive and viceversa if it is low. For those who were competitive, their yield was 3.47 $\mathrm{t} \cdot \mathrm{ha} \mathrm{H}^{-1}$ and for those who were not, it was $1.19 \mathrm{t} \cdot \mathrm{ha}^{-1}$; on the other hand, selling prices were 2.8 and $1.1 \$ \cdot k g$ 1 respectively. Due to the above, the variable yield per hectare is the most significant variable, a result that is sustained by Gonzalez and Alferez (2010) who indicate a relationship between productivity and competitiveness, which is given by production costs and the level of yield, so a high productive potential makes a product more competitive and this is because the area has great agricultural potential and shows yields of up to 8 tons. The information obtained in the survey allowed calculating an average yield of $4.8+$ $1.13 \mathrm{t}$ (an amount that would be additional without the presence of disasters).

\section{Conclusions}

Neoliberal policy has been insufficient to boost the competitiveness of maize producers; however, peasants have looked for ways to improve the
Puede decirse que la tecnología agrícola puede mejorarse y con ello el rendimiento y directamente la competitividad y así contribuir a mejorar el ingreso y el nivel de vida de los maiceros como lo expresaron Shiferaw, et al. (2008); Kijima, et al. (2008). Para ello es necesario que se hagan estudios para generar, transferir y evaluar tecnologías apropiadas.

Rojas (2013) señala que, la crisis económica que acompaña al modelo de desarrollo neoliberal ha impactado de manera diferenciada al sector agrícola, agudizando la polarización de la estructura económica y social en el campo mexicano, y una de sus consecuencias es la migración y su incursión en el empleo no agrícola. En ese sentido, el $16.8 \%$ de los entrevistados mencionó que se dedica a actividades no agrícolas; de este porcentaje, el $31.3 \%$ es del agrosistema Sierra y el $35 \%$ de Tlachichuca. Estadísticamente ( $\mathrm{t}=-1.585 ; P=0.116)$ no se encontró diferencia en los rendimientos obtenidos entre los que realizaron actividades no agrícolas (2.8 th $\left.\cdot \mathrm{a}^{-1}\right)$ y los que solo trabajaron en el campo (3.3 th.ha-1), lo cual significa que el no trabajar en el campo de tiempo completo no afectó demasiado la producción agrícola, en gran medida por el uso de mano de obra familiar.

Para el análisis de regresión logística se consideró competitivo a todos los campesinos que obtienen una relación costo beneficio positiva, existe un $88.2 \%$ de posibilidades de acierto en el resultado de la variable dependiente de competitividad, aportado por la regresión logística. En el cálculo de competitividad a través de la matriz de análisis de políticas (MAP), el $88.4 \%$ de los entrevistados resultó competitivo a precios de mercado, por lo que se asume que las variables que influyeron en el modelo 
productivity of their plots by lowering their production costs, which makes them competitive. This study showed that although there are certain policies focused on maize production, these do not necessarily impact as expected, since their characteristics do not always adjust adequately to the demands of peasants and to the physical characteristics of the region where they want to implement them.

Although agricultural machinery and the use of agrochemicals would be expected to make a difference in maize production, this study showed that they are not elements that demonstrate a direct relationship with the competitiveness of the region's maize producers. In this sense, production per hectare and sales price are variables that are related to the competitiveness of maize. Likewise, the agrosystems analysis allowed demonstrating that there is a direct relationship between the adoption of technology and productivity, since the agrosystems with a higher score in the IATF and the GETI turned out to have higher productivity than those that obtained a lower score.

End of English version

\section{References}

Aceves, R. E., López, P., Mendoza, R., Herrera, C. B., Cortés, F. J..., Muñoz, O. (1993). Identificación de nuevos materiales de maíz para incrementar la productividad en tres agrosistemas del Plan Puebla. En Informe Técnico del Plan Puebla 1993, coordinado por Vargas L., S., Peña O., B., \& Castro R., D. 16-17. Puebla, Pue. CPCEICADAR.

Aldana U., Foltz, J., Barham, J., \& Useche, P. (2011). Sequential adoption of package technologies The dynamics of stacked trait corn adoption. American Journal of Agricultural Economics, 93(1): 130-143.

Altieri A., M. Á. (2009). "Agroecology, Small Farms, and Food Sovereignty". Monthly Review, 61 (03):102-111.

Altieri A., M Á., \& Nicholls, C. (2007). Biodiversidad y manejo de plagas en agroecosistemas. Ed. Barcelona: Icaria. 247 p.

Blanco M., L. (1980). "Función de la información y algunos factores sicosociales asociados con el uso de innovaciones agrícolas". Tesis de maestría Colegio de Postgraduados. México. 135 p. obtenido a través de la regresión logística son las que más peso tienen sobre la variable de competitividad.

Se infiere que la maquinaria agrícola no tiene efectos significativos en la productividad y la competitividad. Sin embargo, el precio de venta es una de las variables que favorece o pone en desventaja la Competitividad; factor que ya ha sido abordado por Flores, García, Mora y Pérez (2014) y García et al. (2006), es decir un precio alto hace que el productor sea más competitivo y viceversa si es bajo. Para aquellos que fueron competitivos, su rendimiento fue de $3.47 \mathrm{t} \cdot h \mathrm{a}^{-1} \mathrm{y}$ para los que no, fue de $1.19 \mathrm{t} \cdot \mathrm{ha}^{-1}$, por otra parte, los precios de venta fueron de 2.8 y $1.1 \$ \cdot \mathrm{kg}^{-1}$ respectivamente, debido a lo anterior, la variable rendimiento por hectárea es la variable más significativa, resultado que es sostenido por González y Alférez (2010) quienes argumentan una relación entre la productividad y la competitividad, la cual está dada por los costos de producción y el nivel de rendimiento, por lo que un potencial productivo alto hace a un producto tener mayor competitividad y esto es debido a que la zona tiene un gran potencial agrícola y exhibe rendimientos de hasta 8 toneladas. Con la información obtenida en la encuesta, se encontró un rendimiento promedio de $4.8+1.13 \mathrm{t}$, (cantidad que sería adicional sin la presencia de siniestros).

\section{Conclusiones}

La política neoliberal ha sido insuficiente para impulsar la competitividad de los productores de maíz; sin embargo, los campesinos han buscado diversas formas que les permiten mejorar la productividad de sus parcelas, bajando el costo de producción, lo cual los hace competitivos. El estudio demostró que a pesar de que hay ciertas políticas enfocadas a la producción del maíz, estas no necesariamente impactan como se espera, ya que las características de estas no siempre se ajustan de manera adecuada a las exigencias de los campesinos y a las características físicas de la región donde se desean implementar.

Aunque se esperaría que la maquinaria agrícola y el uso de agroquímicos marcaran la diferencia en cuanto a la producción de maíz, el estudio demostró 
Bolton A., Studdert, A., \& Echeverría, E. (2004). Utilización de estiércol de animales en confinamiento como fuente de recursos de la agricultura. Revista Agrícola de Producción Animal, 24(2): 53-73.

Buffet G., H. (2013). Story 28, "Can Smarter Carrots save the soil?". In: Forty Chances, Finding hope in a Hungry World. Edit. Simon and Schuster. New York, 273-282.

Byerlee D., \& de Polanco, E. (1986). Farmers' stepwise adoption of technological packages: Evidence from the Mexican Altiplano. American Journal of Agricultural Economics, 68 (3): 519-527.

Centro de Estudios de las Finanzas Públicas-CEFP. (2007). El Proceso de Desgravación Arancelaria del Maíz y el Frijol en el Marco del TLCAN, 1994-2008. Palacio Legislativo de San Lázaro, México, Cámara de Diputados LX Legislatura.

Centro Internacional de Mejoramiento de Maíz y TrigoCIMMYT. (1993). "La adopción de tecnologías agrícolas". En: Guía para el diseño de encuestas. México, D.F.: CIMMYT, 88 p.

Comisión Estatal del Componente de Desarrollo de Capacidades y Extensionismo Rural-CECODECAER. (2013). “Plan Estratégico para la Operación Anual el Componente de Desarrollo de Capacidades y Extensionismo Rural del Estado de Puebla". INCA Rural, BUAP CEC'S, PUEBA SEDATU y SAGARPA, $63 \mathrm{p}$.

Damián H., M. Á., \& Ramírez, B. (2008). Dependencia científica y tecnologías campesinas. El caso de los productores de maíz del estado de Tlaxcala. Economía y Sociedad. 21: 59-76.

Damián H., M. Á., Ramírez, B., Parra F., Paredes J., A., Gil, A..., Cruz, L. (2009). Método para evaluar el empleo adecuado de tecnología entre los maiceros del estado de Tlaxcala. Revista de Geografía agrícola, 43 (33): 33-50.

Damián H., M. Á., Cruz, L., Ramírez, B., Juárez, D., Andrade, M., \& Espinosa, S. (2010). "Innovaciones recomendadas para mejorar la producción de maíz de temporal en el DDR de Libres, Puebla". En: Manual Técnico. BUAPCONACYT, $70 \mathrm{p}$.

Damián H., M. Á.; Cruz, L., Orozco, C., Aragón, A., Sangermán M., J., \& López J., F. (2012). Manejo del maíz en Cohetzala, Puebla, México: entre lo local y lo global. Estudios Sociales. 20 (40), 313-333.

Del Valle M., \& Perales, A. (2014). "Globalización crisis y políticas públicas en el sector agroalimentario de México". En: el siglo XXI. Mundi-Prensa, México, pp. 200 que no son elementos que demuestren una relación directa con la competitividad de los maiceros de la región. En este sentido la producción por hectárea y precio de venta, son variables que se relacionan con la competitividad del maíz. Asimismo, el análisis por agrosistemas permitió demostrar que hay una relación directa entre la adopción de tecnología y la productividad, ya que los agrosistemas con un mayor puntaje en el IATF y el GETI, resultaron tener una mayor productividad con respecto a aquellos que obtuvieron un menor puntaje.

Fin de la versión en español

Díaz C., H., Jiménez, S., Carrillo, R., González E., P., \& Valseca F., R. (1991). “Plan Puebla 1967-1990: el papel de cada uno de los elementos de la estrategia en el éxito global de la operación". En: avances de la investigación del Centro de Estudios del Desarrollo Rural, Colegio de Postgraduados, Centro de Estudios del Desarrollo Rural. México, 162 p.

Doss C., R. (2006). Analyzing technology adoption using microstudies: Limitations, Challenges, and Oportunities for Improvement. Agricultural Economics, 37 (2-3): 200-219.

Economic Report of the President. (2006). Washington D.C., Transmitido al Congreso de los Estados Unidos febrero 2006, 175 p.

Encuesta Nacional de Ingresos y Gastos de los Hogares (2012)-ENIGH. Módulo de condiciones socioeconómicas. Tabulados básicos. INEGI.

Feder, G., Just, E., \& Zilberman D. (1985). Adoption of Agricultural Innovations in Developing-Countries- a Survey. Economic Development and Cultural Change, 33 (2): 240-275.

Feder G., \& Umali, D. (1993). The adoption of Agricultural Innovations -a review. Technological Forecasting and Social Change, 43 (3-4) 184-250.

Flores C., L. A., García J., A., Mora J., S., \& Pérez, F. (2014), Producción de maíz en el estado de Puebla un enfoque de equilibrio espacial para identificar las zonas productoras más competitivas. Agricultura sociedad y desarrollo, (11):223-239.

García J., A., \& Ramírez, R. (2012). "Demanda de Semilla Mejorada de Maíz en México". En: Identificación de 
Usos y Zonas de Producción con Mayor Potencial de Crecimiento. Centro Internacional de Mejoramiento de Maízy Trigo (CIMMYT). Texcoco, Estado de México, 156 p.

García S., J. A., Rodríguez, G., Sáenz, A., \& Rebollar, S. (2006). Políticas para mejorar la competitividad de la producción de maíz y frijol en México. Revista Fitotecnia Mexicana, 29 (Núm. Especial2): 115-121.

Galindo G., G. (1996). Las innovaciones agrícolas en el desarrollo de México. Problemas del Desarrollo, 27 (105) 69-81.

Galindo G., G. (2004). Estrategias de difusión de innovaciones agrícolas en México. Revista Chapingo. Serie Zonas Áridas, (3): 73-79.

González E., A., \& Alférez, M. (2010). Competitividad y Ventajas Comparativas en la producción de maíz en México, Revista Mexicana de Ciencias Agrícolas, 3 (11) 3: 381-396.

Harwood, R. (1979). Small Farm development: Understanding and Improving Farming Systems in the Humid Tropics. Boulder Colorado. Westview Press.

Hayami Y., \& Ruttan, W. (1973). Desarrollo Agrícola: Una perspectiva internacional. Baltimore: Jhon Hopkins Press.

Instituto Nacional de Estadística Geografía e InformáticaINEGI. (2010a). Conteo de población y vivienda 2010. Población y escolaridad. Online. 2010 http://cuentame. inegi.org.mx/poblacion/escolaridad.aspx?tema $=P$

Instituto Nacional de Estadística Geografía e InformáticaINEGI. (2010b). Conteo de población y vivienda 2010. Online, http://inegi.org.mx/inegi/default.aspx], México.

Instituto Nacional de Estadística Geografía e InformáticaINEGI. (2010c). Online, http://cuentame.inegi.org.mx/ poblacion/rur_urb.aspx?tema=P. México.

Juárez R., D., Fragoso, C., Ferrera, C., Sandoval, C., Turrent, F., \& Ocampo, I. (2009). "Procesos biológicos del suelo en la restauración de agroecosistemas". En: Manejo agroecológico de sistemas. López J. F.; Aragóri, G. y Tapia A., M. (Eds.). 1 Simposio en Manejo Agroecológico de Sistemas. Benemérita Universidad Autónoma de Puebla. ISBN: 978-607-487-111-1, Puebla, México. 37-64.

Juárez S., J. P., \& Ramírez, B. (2008). “Adopción de tecnología y rendimiento en el cultivo del maíz en una región campesina del estado de Puebla". En: Regiones y Desarrollo Sustentable. Publicación semestral del estado de Tlaxcala A.C. Año VII, Julio-Diciembre, Año IX, Enero-Junio, 2008, (13-14) 137-151.
Kijima, Y., Otsuka, K., \& Sserukuuma, D. (2008). Assessing the impact of NERICA on income and poverty in central and western Uganda. Agricultural Economics, (38): 327-337.

Khonje, M., Manda, J., Arega, A. \& Kassie, M. (2015). Analysis of Adoption and Impacts of Improved Maize Varieties in Eastern Zambia. World Developtment. (66):695-706.

Lambrecht, I., Vanlaue, B., Merckx, R., \& Maertens, M. (2014). Understanding the process of technology adoption. Mineral Fertilizer in Eastern DR. Congo. World Development, (59): 132-146.

Lee D., R. (2005). Agricultural Sustainability and Technology adoption: Issues and Policies for developing countries. American journal of Agricultural Economics, 87 (5): 1325-1334.

Martínez M., G. C., Dorward, P., \& Rehman, T. (2012). Factors influencing adoption of Improved Grassland Management by Small-Scale Dairy Farmers in Central Mexico and the implications for Future Research on smallholder adoption in developing Countries. Liverstock Science, (152): 228-238.

Mendoza M., S. (1987). "Marco Conceptual de la transferencia, validación, difusión y adopción de tecnología agrícola". En: Nociones preliminares. Inmemorial del taller de Metodología y Normatividad en la Operación del Programa de Generación Tecnológica. Secretaria de Agricultura y Recursos Hidráulicos, Instituto Nacional de Investigadores Forestales y Agropecuarias. México, 215 p.

Pearson, R. (2003). La fuerza de tracción animal: Una revisión de la tecnología disponible en el mundo. In: Arriaga, C., Castelán, O., Velázquez, L. (Comp.). 2003. Investigación en animales de trabajo para el desarrollo rural. UAEM. Ed. CIGOME. Estado de México, 15-30.

Posada, M. (1995). Enfoque de sistemas y racionalidad de los productores. Elementos para el análisis de Situaciones de producción específicas: el caso de los productores pampéanos. Realidad Económica, 19:213-220.

Ramírez V., B. (1999). Agricultural policy and development in Mexico: an evaluation of a twenty years' experience in the state of Puebla. Ph.D. Dissertation, The Latin American Studies Program, Tulane University, Louisiana, USA, 23-36.

Ramírez V., B., Ramírez, G., Juárez J., P., \& Cesín, A. (2007). Tecnología e implementos agrícolas: estudio longitudinal en una región campesina de Puebla, México. Revista de Geografía Agrícola. Universidad Autónoma de Chapingo (UACh), 38: 55-70. 
Ramírez V., B., \& Juárez J., P. (2008). Adopción de tecnología y rendimiento del maíz en una región campesina del estado de Puebla. En Regiones y Desarrollo Sustentable, 125-151.

Regalado, L. J., L. Jiménez S., J. Laird R., N. Estrella Ch., J. A. Paredes S., \& B. Ramírez V. (1996). Factores asociados a la utilización de la tecnología de alta productividad entre productores de maíz de temporal. Agrociencia, 30: 139-145.

Ruttan V., W., \& Hayami, Y. (1989). El cambio tecnológico inducido en la agricultura en Agricultura y Sociedad, 53: 19-75.

Rojas T., J. (2013). Migración y exclusión social de los trabajadores del campo. Revista Universitaria, Universidad Pedagógica Nacional, México, 11:12-14.

Secretaría de Agricultura Ganadería Desarrollo Rural Pesca y Alimentación-SAGARPA, (2014). Secretaría de Agricultura, Ganadería, Desarrollo Rural Pesca y Alimentación. Padrón de Productores del Programa PROAGRO.

Secretaría de Desarrollo Agrario y Territorial Urbano -SEDATU. (2012). “Boletín de prensa del 13 de mayo del 2012, http:// www.sedatu.gob.mx/sraweb/noticias/noticias-2012/ mayo-2012/12268/.

Secretaría de Desarrollo Social-SEDESOL. (2012). Disponible en: http://www.microrregiones.gob.mx/catloc/LocdeMun.as px?tipo $=$ clave \&campo=loc\&ent $=21 \&$ mun $=179$.

Seixas M., A., \& Ardila, J. (2002). La Agricultura de América Latina y el caribe, sus desafíos y oportunidades, desde la óptica del cambio tecnológico, Tercera reunión Internacional de FORA GRO. Brasilia, Abril: 1-13.

Sistema de Información Agroalimentaria-SIAP. (2013). "Producción anual, cierre de la producción agrícola por cultivo", disponible en: "http://www.siap.gob.mx/ cierre-de-la-produccion-agricola-por-cultivo/" http:// www.siap.gob.mx/cierre-de-la-produccion-agricolapor-cultivo/ consultado septiembre 2014.

Sistema de Información Agroalimentaria-SIAP. (2014). "Producción anual, cierre de la producción agrícola por cultivo", disponible en: "http://www.siap.gob.mx/ cierre-de-la-produccion-agricola-por-cultivo/" http:// www.siap.gob.mx/cierre-de-la-produccion-agricolapor-cultivo/ consultado septiembre 2016.

Shiferaw B., A., Kebede, A., \& You, L. (2008). Technology adoption under seed Access constraints and the economic impacts of improved pigeonpea varieties in Tanzania. Agricultural Economics, (39): 309-323.
Solow, R. (1979). "El cambio técnico y la función de la producción agregada". En: Rosengberg, Nathan. Economía del Cambio Tecnológico. FCE, México, 319336.

Sweenely, S., Steigerwald, G., Davenport, F., \& Eakin, H. (2013). Mexican maize production: Evolving organizational and spatial structures since 1980. Applied Geography. 39: 78-92.

Taboada G., O. R. (1996). Diversidad de los maíces criollos en el Valle de Serdán, Puebla. Tesis Profesional. Departamento de Fitotecnia. Universidad Autónoma Chapingo. 130.

Turrent Fernández, A., Cortés Flores, J. I., Mendoza Robles, R., Alonso, J. L., Juan Díaz, C. B..., Inzunza Parra, E. (1994). Desarrollo de un prototipo de explotación agropecuaria familiar para el Distrito de Desarrollo Rural de Cholula, Plan Puebla. Centro de Edafología, Centro de Enseñanza, Investigación Producción de Maíz y Pluriactividad de los Campesinos en el Valle de Puebla, México Capacitación para el Desarrollo Agrícola Regional, Colegio de Postgraduados. Montecillo, México.

Turijan A., T., Damián M., Á., Ramírez, B., Juárez J., P., \& Estrella, N. (2012). Manejo Tradicional e innovación tecnológica en San José Chiapa, Puebla. Revista Mexicana de Ciencias Agrícolas, 3 (6). 1085-1100.

Turijan A., T., Ramírez, B., Damián M., Á., Juárez J., P., \& Estrella, N. (2015). Uso de remesas para la adquisición de tecnología agrícola en maíz en San José Chiapa, Puebla, México. Revista Electrónica Nova Ciencia, 14. 7 (2): 674-693.

Villa V., J., Robles, E., Barrueta, J., \& Herrera, V. (2010). El maíz no es una cosa. Es un centro de origen. Editorial Itaca. México. IBSN:978-607-7957-25-6, 160 p.

Williams G., W. (2007). El cambio técnico y la agricultura. La experiencia de los Estados Unidos e implicaciones para México". Revista mexicana de Agronegocios, Vol. 11 (20): 209-220.

Zeller, M., Diagne, A., \& Mataya, C. (1998). Market access by smallholder farmers in Malawi: Implications for technology adoption, agricultural productivity and crop income. Agricultural Economics, 19 (1-2): 219-229. 
